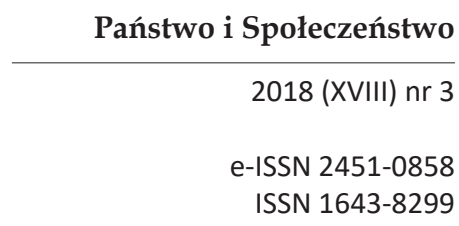

doi.org/10.31749/pismzp2018/20843

Ewelina Wędrowska ${ }^{1}$, Marek Libura ${ }^{2}$, Maciej Chmielarski ${ }^{1}$, Bartłomiej Grad ${ }^{2}$, Joanna Golińska ${ }^{1}$, Tomasz Senderek ${ }^{3}$, Rafał Wojciechowski ${ }^{4}$, Jakub Siudut ${ }^{5}$, Piotr Kopiński ${ }^{1}$

1. Collegium Medicum Uniwersytetu Mikołaja Kopernika, Wydział Lekarski, Zakład Genoterapii

2. Uniwersytet Rolniczy im. H. Kołłątaja, Wydział Leśny, Zakład Fitopatologii Leśnej,

Mykologii i Fizjologii Drzew, Instytut Ochrony Ekosystemów Leśnych

3. Krakowska Akademia im. Andrzeja Frycza Modrzewskiego, Katedra Fizjologii i Patofizjologii, Wydział Lekarski i Nauk o Zdrowiu

4. Klinika Reumatologii i Układowych Chorób Tkanki Łącznej, Szpital Uniwersytecki nr 2 im. dr. Jana Biziela

5. Krakowskie Centrum Badań i Technologii Medycznych, Krakowski Specjalistyczny Szpital im. Jana Pawła II

\title{
OBRAZ CYTOIMMUNOLOGICZNY PŁYNU STAWOWEGO W REUMATOIDALNYM ZAPALENIU STAWÓW. WSTĘPNA OCENA WPŁYWU LECZENIA METOTREKSATEM I METYLOPREDNIZOLONEM
}

\author{
Autor korespondencyjny: \\ Ewelina Wędrowska, Zakład Genoterapii Collegium Medicum UMK \\ ul. M. Skłodowskiej-Curie 9, 85-094 Bydgoszcz, \\ e-mail: ewelina.wedrowska@gmail.com
}

\section{Streszczenie}

Wprowadzenie: Pobranie płynu stawowego w reumatoidalnym zapaleniu stawów (RZS) umożliwia wgląd w miejscową aktywność zapalenia. W patogenezie zmian stawowych główną rolę pełnią komórki $\mathrm{T}$, w tym dodatnie $\mathrm{z}$ ligandami receptorów śmierci: Ligand Fas (FasL) i TRAIL (TNF-related apoptosis-inducing ligand). W terapii RZS lekiem pierwszego rzutu jest metotreksat (MTX), w leczeniu uwzględnia się m.in. glikokortyko- 
steroidy (metyloprednizolon) i niesteroidowe leki przeciwzapalne (NLPZ). Mało wiadomo o wpływie leczenia na profil immunologiczny płynu stawowego w RZS.

Cel pracy: Scharakteryzowanie wpływu leczenia metyloprednizolonem i MTX na obraz cytoimmunologiczny płynu stawowego w RZS.

Materiał i metody: Płyn stawowy pobrano od chorych z RZS leczonych metyloprednizolonem $(n=11)$ i MTX $(n=6)$. Grupę kontrolną stanowili chorzy przyjmujący tylko NLPZ $(\mathrm{n}=19)$. Zbadano całkowitą liczbę komórek (CLK), odsetek krwinek białych i fenotyp subpopulacji limfocytów płynu stawowego, w tym ekspresję FasL i TRAIL na komórkach Th i Tc.

Wyniki: Stwierdzono spadek CLK płynu u chorych leczonych metyloprednizolonem lub MTX. W grupie MTX wzrosła wartość indeksu CD4/CD8 (mediany: 1,2 vs 0,7, p<0,05) w porównaniu z grupą NLPZ. Metyloprednizolon zmniejsza odsetek limfocytów T FasL+ i TRAIL+ (np. mediana CD8+TRAIL+ 12,0\% u leczonych metyloprednizolonem, w porównaniu z 19,2\% w grupie NLPZ, p <0,05; test U-Manna-Whitneya).

Wnioski: W płynie stawowym chorych leczonych metyloprednizolonem wystąpiło obniżenie markerów cytotoksyczności limfocytów w porównaniu z grupą leczoną wyłącznie NLPZ. Równoległe zmiany grupy MTX nie były znamienne. Wysoka wartość indeksu CD4/CD8 w grupie leczonej MTX wynika prawdopodobnie z preferencyjnej eliminacji komórek cytotoksycznych. Badanie cytoimmunologiczne płynu stawowego może mieć znaczenie w ocenie skuteczności leczenia RZS.

Słowa kluczowe: reumatoidalne zapalenie stawów, płyn stawowy, metotreksat, metyloprednizolon

\section{Wprowadzenie}

Reumatoidalne zapalenie stawów (RZS) jest przewlekłą, układową chorobą tkanki łącznej o podłożu autoimmunologicznym, dotyczącą ok. 1\% populacji. Charakteryzuje się nieswoistym, symetrycznym zapaleniem błony maziowej stawów oraz występowaniem licznych zmian pozastawowych. Najbardziej typowymi objawami są narastający ból, sztywność poranna oraz obrzęki małych stawów. Przebieg RZS ma charakter przewlekły, z okresami zaostrzeń i remisji, często agresywny, prowadzący do postępującego niszczenia struktur stawu i tkanek okołostawowych, a w konsekwencji do niepełnosprawności chorego [1-3].

Etiologię RZS poznano tylko częściowo; przyjmuje się, że główną rolę $\mathrm{w}$ patogenezie odgrywają mechanizmy autoimmunizacyjne, w tym przede wszystkim aktywowane limfocyty T, makrofagi i komórki dendrytyczne, stanowiące źródło cytokin prozapalnych. Istotne znaczenie przypisuje się też limfocytom $B$ jako bezpośrednio odpowiedzialnym za syntezę m.in. jednego z markerów immunologicznych RZS (czynnika reumatoidalnego) oraz pojawienie się przeciwciał anty-cytrulinowych, wysoce swoistych dla choroby [4-8]. Niewątpliwie ważną rolę w rozwoju choroby odgrywają czynniki genetyczne; ustalono, że ryzyko zachorowania na RZS jest kilkukrotnie wyższe u osób z ekspresją niektórych antygenów układu zgodności tkankowej klasy II (zwłaszcza HLA-DR1B 
i -DRB4). Wskazuje się, że zakażenia wirusowe (np. EBV) i bakteryjne (jak Porphyromonas gingivalis), mogą $\mathrm{w}$ drodze reakcji krzyżowej uruchomić proces autoimmunizacji u predysponowanych genetycznie osób $[2,4]$.

Postępy w zrozumieniu patofizjologii choroby prowadzą do opracowania nowych strategii terapeutycznych, jednak wciąż leczenie RZS ma na celu przede wszystkim osiągniecie remisji klinicznej, tj. uzyskania stanu bez dodatkowych cech aktywności choroby. Stosowane są niesteroidowe leki przeciwzapalne (NLPZ), glikokortykosteroidy (GKS) oraz leki modyfikujące przebieg choroby (LMPCh): syntetyczne i biologiczne. Właśnie LMPCh pełnią kluczową rolę $\mathrm{w}$ farmakoterapii choroby. Ich zastosowanie pozwala na znaczną poprawę kliniczną i powoduje obniżenie stężenia czynnika reumatoidalnego oraz normalizację markerów stanu zapalnego (CRP i OB). Najczęściej stosowanym lekiem z tej grupy jest metotreksat (MTX), uznawany za najskuteczniejszy i wybierany jako lek pierwszego rzutu, zwłaszcza u chorych z agresywnym przebiegiem RZS. MTX jest pośrednim inhibitorem syntezy cytokin prozapalnych i metaloproteinaz. Jego korzystny wpływ wiąże się m.in. z hamowaniem proliferacji limfocytów, syntezy leukotrienów, interleukiny-2 i samego czynnika reumatoidalnego $[9,10]$. Jednak tylko w pojedynczych badaniach oceniono bezpośredni wpływ MTX na parametry biochemiczne i immunologiczne we krwi, tym mniej więc wiadomo o tych parametrach w płynie stawowym chorych. Drugą grupę powszechnie stosowanych środków w RZS stanowią glikokortykoidy, najczęściej metyloprednizolon. Glikokortykoidy wdrażane są w celu szybkiego wyciszenia reakcji zapalnej, a podawanie ich w skojarzeniu z lekami modyfikującymi przebieg choroby pomaga m.in. zahamować tworzenie ubytków kostnych w przebiegu RZS [11]. Zgodnie z obowiązującym algorytmem leczenia reumatoidalnego zapalenia stawów wg zaleceń EULAR 2016 [12] w przypadku braku skuteczności dotychczasowej terapii - a wcześniej u młodych chorych $\mathrm{z}$ agresywną postacią RZS - wdrażane są leki biologiczne. Najczęściej są to przeciwciała monoklonalne, skierowane przeciwko wybranym czynnikom przeciwzapalnym $[13,14]$.

Pomimo stosowania adekwatnego leczenia konwencjonalnego nie udaje się całkowicie powstrzymać postępujących zmian stawowych. Z kolei nieleczone RZS skutkuje poważną niepełnosprawnością narządu ruchu i przedwczesnym zgonem [15]. Należy podkreślić, że narząd ruchu, co oczywiste, nie jest jedynym obszarem patologii RZS, nawet nie jest do końca pewne, czy chronologicznie pierwszym - ale z pewnością najbardziej charakterystycznym. Na nim też skoncentrowano się w niniejszej pracy.

Zbadano w niej poszczególne populacje leukocytów w miejscowym, dotyczącym stawów, odczynie zapalnym RZS. Zmiany zachodzące w tkankach stawu znajdują odzwierciedlenie w składzie płynu stawowego, dokonano zatem próby scharakteryzowania obrazu cytologicznego i immunologicznego płynu stawowego chorych z RZS. Uwzględniono zmianę całkowitej liczby komórek, a także odsetek populacji krwinek białych płynu. W przypadku komórek T zbadano kom- 
pozycję ich subpopulacji (CD4+, w uproszczeniu traktowanych jako komórki pomocnicze Th, oraz CD8+, jako komórki cytotoksyczne Tc). Określono odsetek komórek T z ekspresją antygenu wczesnej aktywacji HLA-DR. W pracach nad patogenezą RZS wykazano oporność fibroblastów łuszczki stawowej (fibroblast-like synoviocytes, FLS) na proces apoptozy [16,17]. W związku z tym zwrócono szczególną uwagę na możliwy potencjał cytotoksyczny komórek CD4+ i CD8+ z koekspresją ligandów receptorów śmierci FasL + i TRAIL+ (TNF-related apoptosis-inducing ligand). Prawdopodobnie są one zdolne do indukcji programowanej śmierci komórek docelowych. Mogą tym samym działać dwojako: niszczyć tkanki stawowe, ale też i hamować zapalenie, poprzez wywołanie apoptozy komórek łuszczki. Pierwsze z tych potencjalnych działań nie jest korzystne, drugie tak. Mając tak określony punkt odniesienia (obraz płynu stawowego u chorych nieleczonych lub tylko leczonych lekami grupy NLPZ), zajęto się w niniejszej pracy dokładną oceną wpływu leczenia metotreksatem i metyloprednizolonem na obraz cytoimmunologiczny płynu chorych z RZS.

\section{Material i metody}

Grupy chorych

Płyny stawowe pozyskano z Oddziału Urazowo-Ortopedycznego Samodzielnego ZOZ MSW Szpitala w Krakowie (ul. Kronikarza Galla 25) oraz z Kliniki Reumatologii i Układowych Chorób Tkanki Łącznej Szpitala Uniwersyteckiego nr 2 im dr. Jana Biziela w Bydgoszczy. Chorzy zostali poinformowani o celach i procedurach badania i wyrazili świadomą zgodę na swój udział (zgoda Komisji Bioetycznej UMK nr 709/2016) Włączono chorych: 1) leczonych tylko lekami grupy NLPZ - doustnie lub miejscowo, zwykle od wielu miesięcy (lub nieleczonych), w szczególności nieleczonych preparatami GKS ani LMPCh (n=19); 2) leczonych lekami grupy NLPZ i preparatami GKS, zwykle metyloprednizolonem 4-8 mg p.o. (n=11); 3) leczonych lekami grupy NLPZ i MTX $(n=6)$, dawka $15 \mathrm{mg}$ na tydzień. Chorzy przyjmowali leki przez co najmniej miesiąc przed pobraniem płynu stawowego (artropunkcji).

Dane demograficzne badanych chorych, a także podstawowe informacje kliniczne przedstawiono w tabeli 1 .

\section{Badanie cytologiczne płynu stawowego}

Punktowano staw kolanowy. Uzyskiwano kilka-kilkanaście mililitrów płynu, zwykle zapalnego typu II (rzadko III) [18]. Obliczano całkowitą liczbę komórek w płynie stawowym przy użyciu komory Bürkera (liczbę komórek zliczano w 25 małych kwadratach, mnożono przez rozcieńczenie i wyrażano w dziesiątkach tysięcy; wynik przedstawiono jako liczbę krwinek białych w $1 \mathrm{ml}$ płynu). Żywotność komórek badano z użyciem błękitu trypanu (płyn mieszano z barw-




nik prezentowano jako odsetek żywych krwinek białych). Szczegóły opisano uprzednio [19].

Tabela 1. Kliniczne i demograficzne dane pacjentów z reumatoidalnym zapaleniem stawów (RZS)

Liczba pacjentów [n]

36

Wiek [lata] (średnia \pm SD)

$23-79(57,86 \pm 11,63)$

Płeć (K:M)

29:7

Czas trwania RZS [miesiące]

(średnia $\pm \mathrm{SD}$ )

$10-160(130,45 \pm 13,42)$

Obecność RF [\% pacjentów]

80

Leczenie NLPZ [\% pacjentów]

100

Leczenie tylko NLPZ [n]

19

Leczenie NLPZ + GKS [n]

11

Leczenie NLPZ + MTX [n]

6

\begin{tabular}{cc}
\hline $\begin{array}{c}\text { CLK (mediana } \pm \text { SEM) } \\
\text { Leczeni tylko NLPZ }\end{array}$ & $1899 \times 10^{3} \mathrm{kom} / \mathrm{ml} \pm 49 \times 10^{3}$ \\
\hline $\begin{array}{c}\text { CLK }[\text { mediana } \pm \text { SEM) } \\
\text { Leczeni NLPZ }+ \text { GKS }\end{array}$ & $728 \times 10^{3} \mathrm{kom} / \mathrm{ml} \pm 81 \times 10^{3}$ \\
\hline $\begin{array}{l}\text { CLK (mediana } \pm \text { SEM) } \\
\text { Leczeni NLPZ }+ \text { MTX }\end{array}$ & $905 \times 10^{3} \mathrm{kom} / \mathrm{ml} \pm 22 \times 10^{3}$ \\
\hline
\end{tabular}

$\mathrm{n}$ - liczba chorych, K - kobiety, M - mężczyźni, SD - odchylenie standardowe (ang. standard deviation, SD), RZS - reumatoidalne zapalenie stawów, RF - czynnik reumatoidalny, NLPZ - niesteroidowe leki przeciwzapalne, CLK - całkowita liczba komórek, SEM - standardowy błąd pomiaru (ang. Standard Error of Measurement, SEM), GKS - glikokortykosteroidy

Preparaty cytologiczne uzyskiwano w drodze cytowirowania $(80 \mathrm{~g}, 5 \mathrm{~min}$., cytowirówka Sigma 4K15, 10740, Osterode am Harz Germany); barwiono równolegle dwiema technikami - hematoksyliną-eozyną (HE) i May-Gruenwald-Giemsą (MGG). Preparaty poddawano analizie cytologicznej, zliczając co najmniej po 200 komórek z preparatu. Obliczano średnie arytmetyczne wartości odsetków: limfocytów, granulocytów (z reguły były to neutrofile, nie odnotowano eozynofilów) i makrofagów (wliczano tu młode monocytoidalne komórki 
układu makrofagów, niekiedy opisywane jako „monocyty”). Szczegóły opisano uprzednio [20].

Badanie immunologiczne plynu stawowego

Zastosowano cytometrię przepływową (FACScan Becton-Dickinson, San Jose, CA, USA) i typowanie fenotypu limfocytów płynu stawowego techniką wielokolorowej immunoflurescencji bezpośredniej. Oznaczano odsetek komórek $\mathrm{T}$ (CD3+), NK [CD3-(CD16+lub56+)], B (CD19+), Th (CD4+) oraz Tc (CD8+). Marker HLA-DR+ w koekspresji z CD3+ wskazywał na poziom wczesnej nieswoistej aktywacji komórek T. Badano odsetek komórek Th i Tc dodatnich z markerami FasL i TRAIL, tj. ligandami receptorów śmierci drogi zewnątrzpochodnej apoptozy; limfocyty FasL+ oraz TRAIL+ traktowano jako komórki o czynności cytotoksycznej.

Procedurę typowania opisano uprzednio [20]. W skrócie, komórki płynu stawowego w ilości $50-150 \times 10^{3} \mathrm{~W}$ pojedynczej próbce inkubowano z nasycającymi objętościami odpowiednich przeciwciał monoklonalnych w temperaturze pokojowej w ciemności (30 min), płukano roztworem PBS z azydkiem sodu $0,1 \%$, utrwalano w $250 \mu \mathrm{L}$ PBS z formaldehydem $2 \%$ i zbierano w cytometrze przepływowym w ciągu 48 godzin od pobrania. Wszystkie wirowania prowadzono przez 8 min. (300g, temp. pokojowa).

$\mathrm{W}$ tabeli 2 zestawiono użyte w pracy mysie przeciwciała monoklonalne, skierowane przeciw antygenom ludzkim; uwzględniono fluorochromy i pasma fluorescencji, w których badano koekspresję odp. markerów. Ludzki antygen CD45 posłużył jako kontrola dodatnia, mysie surowice nieswoiste, zgodne idiotypowo z przeciwciałami swoistymi („roboczymi”) i sprzężone z właściwymi barwnikami - jako kontrola ujemna. Pole limfocytów płynu („,bramka limfocytowa") definiowano w układzie parametrów CD45/SSC (boczne rozproszenie światła, ang. side scatter), a markery podczas analizy bramki ustawiano tak, by nieswoiste dodatnie świecenie komórek we wszystkich badanych w pracy kanałach fluorescencji nie przekraczało 5\% limfocytów. Szczegóły przedstawiono uprzednio [20].

\section{Metody statystyczne}

Posłużono się programem Statistica 12.0. Podstawowe dane demograficzne i kliniczne chorych (tabela 1) zaprezentowano jako średnie wartości zmiennej \pm odchylenie standardowe (standard deviation, SD) i w razie potrzeby zakres wartości zmiennej (minimum-maksimum). Zmienne cytologiczne i immunologiczne, w związku z nieparametrycznym rozkładem zmiennych przedstawiano jako medianę \pm przedział wartości między pierwszym i trzecim kwartylem (zakres wartości minimum-maksimum). Wyniki otrzymane w nierównych liczbowo grupach 
porównano testem U Manna-Whitneya (nieparametrycznym, z powodu wspomnianego wyżej rozkładu zmiennych). Interpretacji wyników obliczeń dokonano na podstawie wartości prawdopodobieństwa (p), stosując poziom istotności statystycznej $\alpha=0,05$ (różnice dla $p<0.05$ uznano za znamienne statystycznie).

Tabela 2. Zestawienie mysich przeciwciał monoklonalnych/surowic użytych w badaniu przeciw antygenom ludzkim lub stosowanych jako kontrola izotypowa, z uwzględnieniem badania koekspresji w poszczególnych próbkach

\begin{tabular}{|c|c|c|c|}
\hline \multirow{3}{*}{$\begin{array}{c}N r \\
\text { Próbki }\end{array}$} & \multicolumn{3}{|c|}{ Pasmo fluorescencji / Kanał cytometru } \\
\hline & FL1 & FL2 & FL3 \\
\hline & FITC & $\mathrm{PE}$ & PE-Cy5 \\
\hline \multirow{2}{*}{1} & \multicolumn{3}{|c|}{ Kontrola izotypowa } \\
\hline & \multicolumn{2}{|c|}{$349526($ FL1+FL2) } & $555750($ FL3) \\
\hline \multirow{2}{*}{2} & CD3 & CD16+CD56+ & CD45 \\
\hline & 561806 & 340042 & 555490 \\
\hline \multirow{2}{*}{3} & CD4 & Fas Ligand & CD8 \\
\hline & 555346 & 564261 & 555368 \\
\hline \multirow{2}{*}{4} & CD8 & TRAIL & CD4 \\
\hline & 557085 & 561784 & 555348 \\
\hline \multirow{2}{*}{5} & CD3 & HLA-DR & CD19 \\
\hline & 561806 & 555561 & 555414 \\
\hline
\end{tabular}

Numery kat. wg firmy Becton-Dickinson Pharmingen ${ }^{\mathrm{TM}}$ (wszystkie przeciwciała);

Pasma fluorescencji cytometru: FL1 (światło zielone), FL2 (jasnoczerwone), FL3 (ciemnoczerwone), FITC, izotiocyjanian fluoresceiny (ang. fluorescein isothiocyanate), PE, fikoerytryna (ang. phycoerythrin), PE-Cy5, fikoerytryna-cyjanina 5 (ang. Phycoerythrin - Cyanine-5).

\section{Wyniki}

Stwierdzono nieznamiennie statystycznie niższe wartości CLK (tabela 1) i niższy odsetek limfocytów w grupie leczonej MTX w porównaniu z grupą przyjmującą tylko NLPZ. Zarówno dla chorych leczonych metyloprednizolonem, jak i MTX obserwowano niższy odsetek makrofagów/monocytów (tabela 3).

Limfocyty $\mathrm{T}$ stanowią główną populację komórek we wszystkich badanych grupach. Wykazano istotne statystycznie, wyższe wartości odsetka limfocytów T i Th oraz niższe - odsetka komórek NK w grupie przyjmującej metyloprednizolon w porównaniu z grupą NLPZ. Jest możliwe, że wzrost odsetka limfocytów T w grupie leczonej metyloprednizolonem wynika ze spadku liczby limfocytów NK. 
Tabela 3. Skład populacji krwinek białych płynu stawowego

\begin{tabular}{cccc}
\hline Populacja & Leczeni NLPZ $^{1}$ & Leczeni prednizonem $^{2}$ & Leczeni MTX $^{3}$ \\
\hline Limfocyty [\%] & $\begin{array}{c}26,5 \pm 3,3 \\
(2-74)\end{array}$ & $\begin{array}{c}32,0 \pm 3,3 \\
(22-50)\end{array}$ & $\begin{array}{c}18,0 \pm 12,5 \\
(10-72)\end{array}$ \\
\cline { 2 - 4 } Monocyty/Makrofagi [\%] & $\begin{array}{c}47,0 \pm 3,9 \\
(8-92)\end{array}$ & $\begin{array}{c}36,5 \pm 5,8 \\
(4-59)\end{array}$ & $\begin{array}{c}24,0 \pm 8,8 \\
(23-68)\end{array}$ \\
\cline { 2 - 4 } Granulocyty [\%] & $\begin{array}{c}16,5 \pm 3,9 \\
(1-88)\end{array}$ & $\begin{array}{c}19,5 \pm 6,1 \\
(9-65)\end{array}$ & $\begin{array}{c}22,0 \pm 10,9 \\
(5-60)\end{array}$ \\
\hline
\end{tabular}

Wyniki przedstawiono jako mediana \pm SEM (zakres); brak różnic znamiennych między grupami.

${ }^{1}$ Leczeni niesteroidowymi lekami przeciwzapalnymi (NLPZ) doustnie bądź miejscowo, bez glikokortykosteroidów i LMChP (w tym leków biologicznych).

${ }^{2}$ Leczeni NLPZ i prednizonem co najmniej od jednego miesiąca przed pobraniem płynu 4-8mg/dzień.

${ }^{3}$ Leczeni NLPZ i metotreksatem (MTX) co najmniej od jednego miesiąca przed pobraniem płynu w dawce $15 \mathrm{mg} /$ tydzień.

Zaobserwowano także niższy odsetek limfocytów cytotoksycznych i zwiększony - limfocytów Th w grupie leczonej MTX w odniesieniu do grupy NLPZ (tabela 4). Istotna statystycznie okazała się wyższa wartość stosunku odsetka limfocytów CD4+ do odsetka limfocytów CD8+ $(1,2)$ dla pacjentów przyjmujących MTX w porównaniu z grupą chorych leczonych wyłącznie NLPZ $(0,7)$. W przypadku grupy przyjmującej GKS stwierdzono niezamienną statystycznie podwyższoną wartość indeksu $(0,85)$ w porównaniu z grupą NLPZ (rycina 1).

Na rycinie 2 uwagę zwraca znamienny statystycznie wzrost odsetka komórek $\mathrm{T}$ dodatnich z markerem aktywacji HLA-DR u chorych leczonych zarówno metyloprednizolonem (58\%), jak i MTX (66,5\%), w porównaniu do grupy przyjmującej tylko NLPZ (27\%). Należy w przyszłości rozważyć użyteczność markera HLA-DR + na limfocytach CD3 + w decyzjach terapeutycznych (rozwinięto poniżej, w części „Dyskusja”).

Grupa leczona metyloprednizolonem charakteryzuje się znamiennymi statystycznie niższymi wartościami odsetków komórek T, Th i Tc dodatnich z FasL w stosunku do grupy leczonej wyłącznie NLPZ. Grupa leczona MTX przyjęła wartości zbliżone do chorych z grupy NLPZ (rycina 3). 
Tabela 4. Odsetek poszczególnych subpopulacji limfocytów w płynie stawowym

\begin{tabular}{lccc}
\hline Rodzaj komórek & Leczeni NLPZ $^{1}$ & $\begin{array}{c}\text { Leczeni } \\
\text { metyloprednizolonem }\end{array}$ & Leczeni MTX $^{3}$ \\
\hline Limfocyty T [\%] & $82,0 \pm 1,9$ & $88,0^{*} \pm 3,9$ & $83,5 \pm 4,6$ \\
& $(33-98)$ & $(55-95)$ & $(66-98)$ \\
\cline { 2 - 4 } Limfocyty Th [\%] & $35,5 \pm 2,0$ & $42,0^{*} \pm 5,2$ & $45,5 \pm 4,8$ \\
& $(6-60)$ & $(21-71)$ & $(28-63)$ \\
\cline { 2 - 4 } Limfocyty Tc [\%] & $50,5 \pm 2,3$ & $49,5 \pm 5,5$ & $38,5 \pm 5,7$ \\
& $(26-76)$ & $(23-80)$ & $(30-67)$ \\
Limfocyty NK [\%] & $12,5 \pm 1,9$ & $7,0 * \pm 3,8$ & $14,5 \pm 4,0$ \\
& $(2-62)$ & $(2-43)$ & $1,5 \pm 0,7$ \\
Limfocyty B [\%] & $1,0 \pm 0,4$ & $1,0 \pm 0,5$ & $(1-5)$ \\
\hline
\end{tabular}

Wyniki przedstawiono jako mediana \pm SEM (zakres);

* $(\mathrm{p}<0,05)$ w porównaniu z chorymi nieleczonymi; test U Manna-Whitneya.

${ }^{1}$ Leczeni niesteroidowymi lekami przeciwzapalnymi (NLPZ) doustnie bądź miejscowo, bez glikokortykosteroidów i LMChP (w tym leków biologicznych).

${ }^{2}$ Leczeni metyloprednizolonem przez co najmniej miesiąc przed pobraniem płynu w dawce 4-8mg/dzień.

${ }^{3}$ Leczeni metotreksatem (MTX) otrzymywali lek przez co najmniej miesiąc przed pobraniem płynu w dawce $15 \mathrm{mg} /$ tydzień.

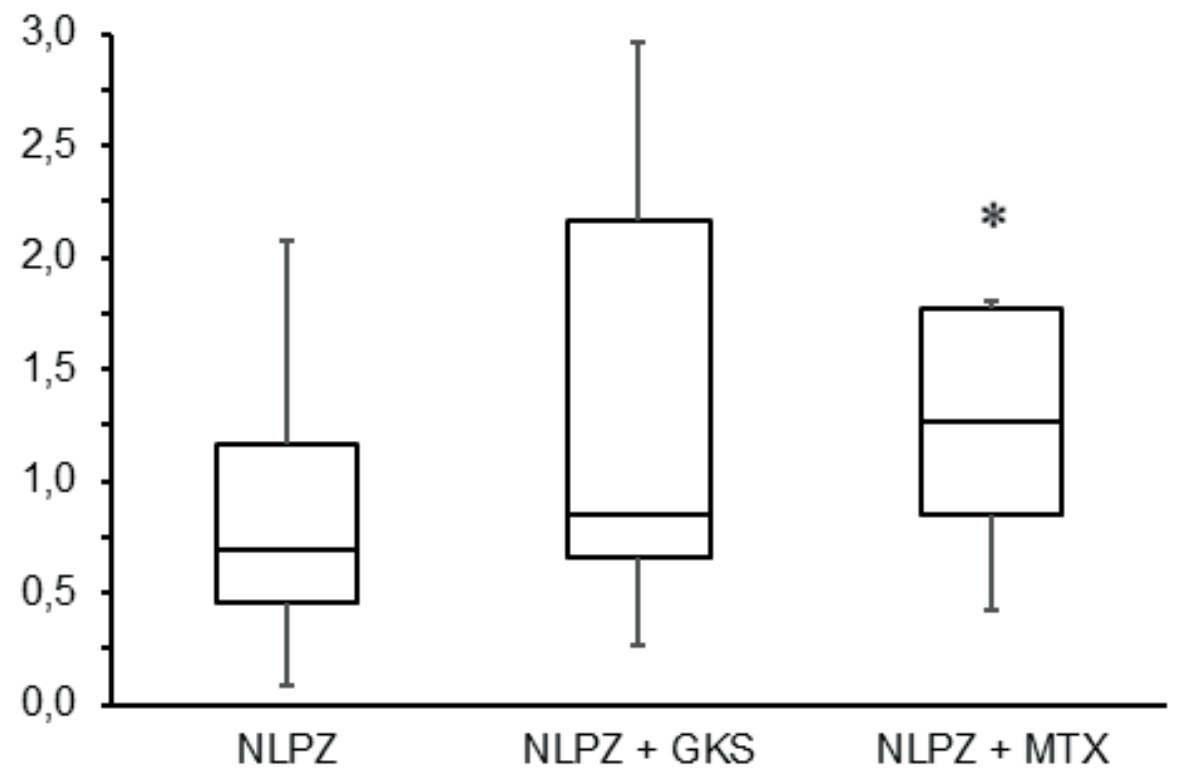

NLPZ - niesteroidowe leki przeciwzapalne, GKS - glikokortykosteroidy, MTX - metotreksat (* p $<0,05 \mathrm{w}$ porównaniu z grupą leczoną NLPZ; test U Manna-Whitneya)

Rycina 1. Wartość indeksu CD4/CD8 w zależności od zastosowanego leczenia 


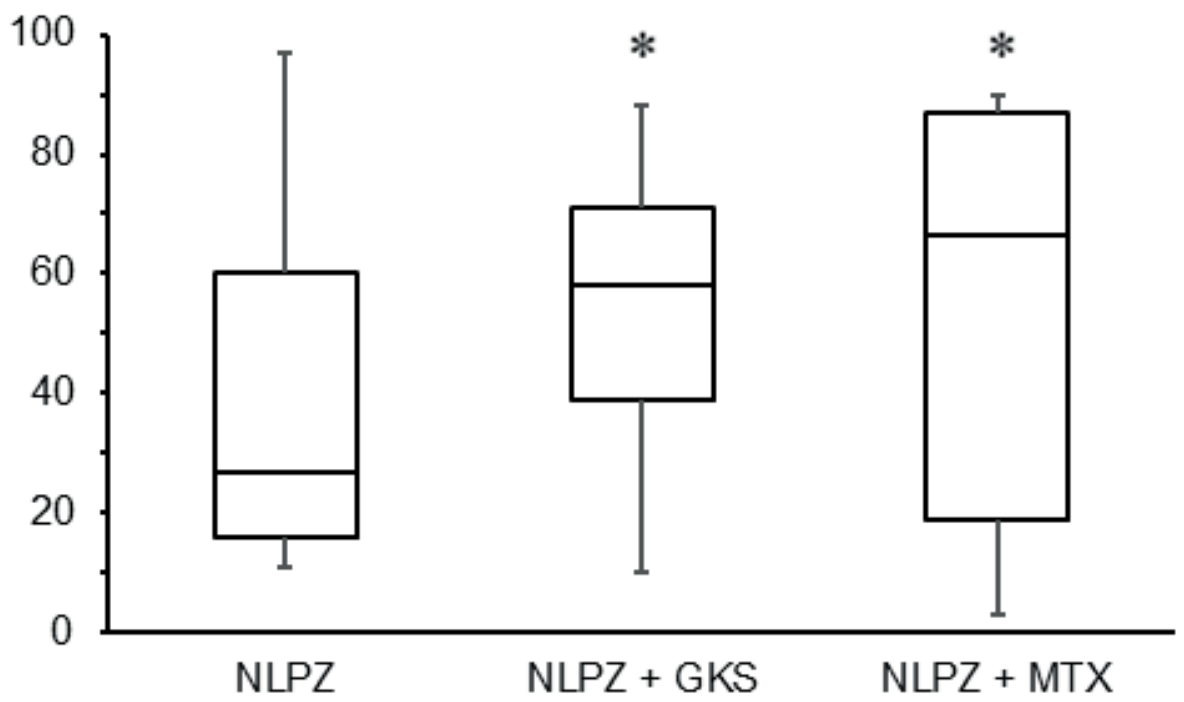

NLPZ - niesteroidowe leki przeciwzapalne, GKS - glikokortykosteroidy, MTX - metotreksat (* p $<0,05 \mathrm{w}$ porównaniu z grupą leczoną NLPZ; test U Manna-Whitneya)

Rycina 2. Odsetek limfocytów T (CD3+) dodatnich z markerem HLA-DR w zależności od zastosowanego leczenia

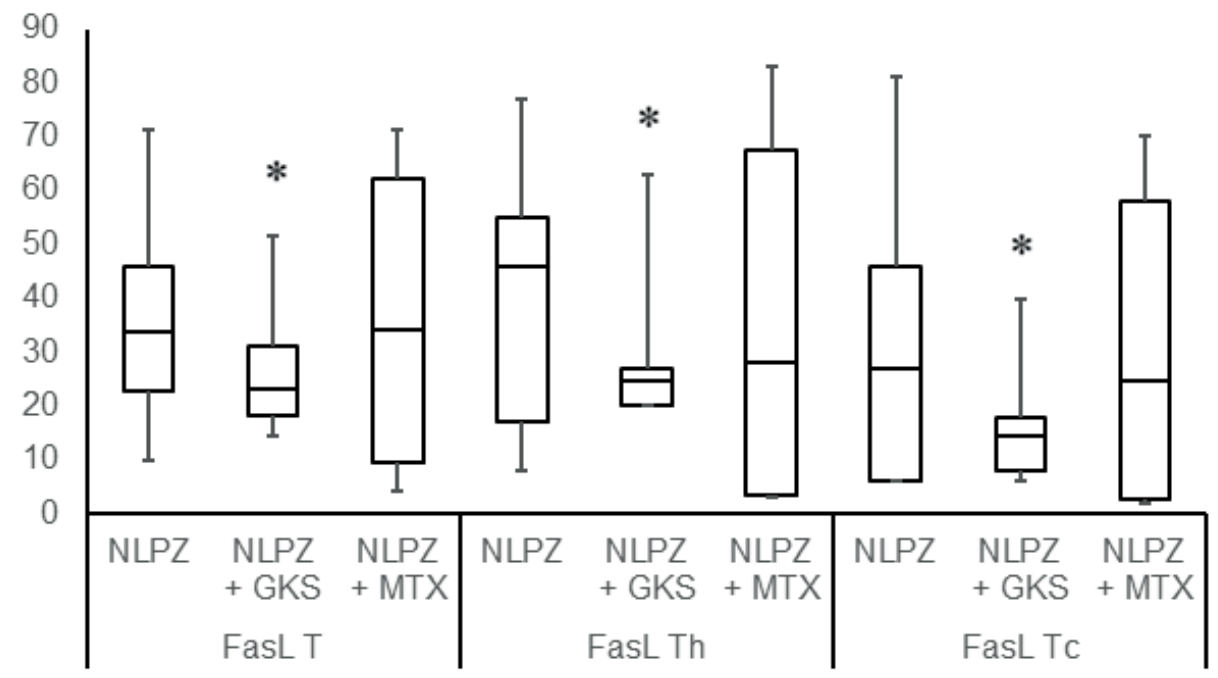

NLPZ - niesteroidowe leki przeciwzapalne, GKS - glikokortykosteroidy, MTX - metotreksat (* p $<0,05 \mathrm{w}$ porównaniu z grupą leczoną NLPZ; test U Manna-Whitneya)

Rycina 3. Odsetki limfocytów Th $(\mathrm{CD} 4+)$ i Tc $(\mathrm{CD} 8+)$ dodatnich z markerem FasL 


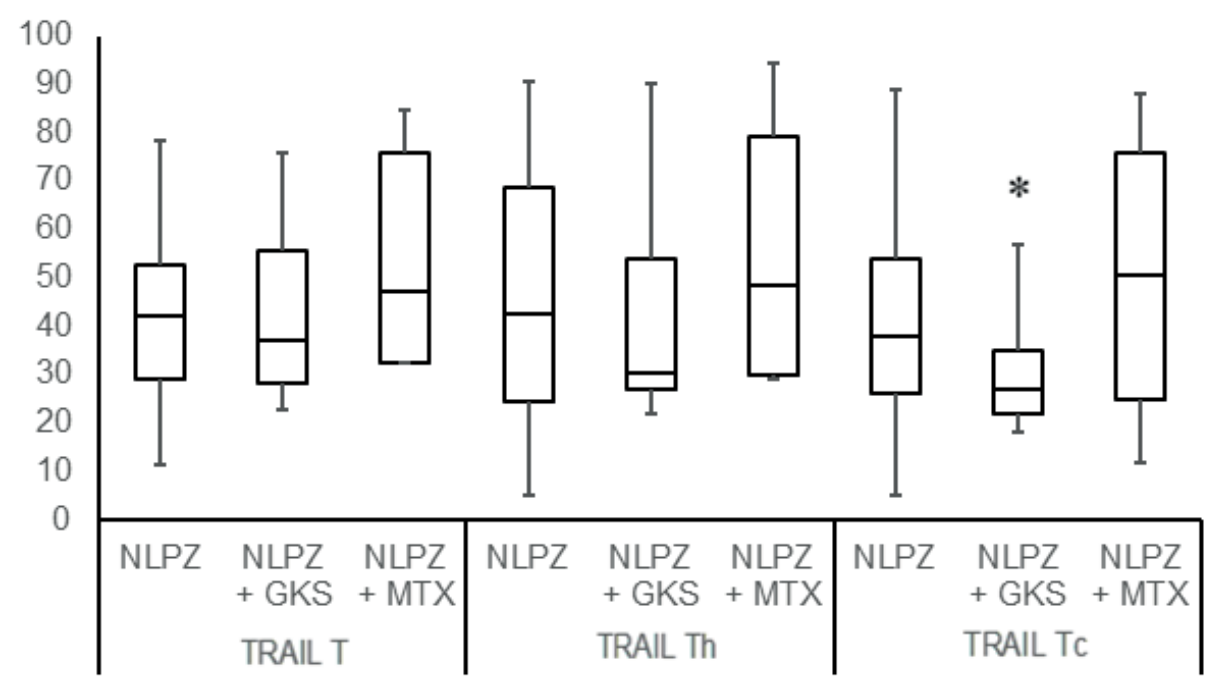

NLPZ - niesteroidowe leki przeciwzapalne, GKS - glikokortykosteroidy, MTX - metotreksat $(*$ p $<0,05 \mathrm{w}$ porównaniu z grupą leczoną NLPZ; test U Manna-Whitneya)

Rycina 4. Odsetki limfocytów Th (CD4+) i Tc (CD8+) dodatnich z markerem TRAIL

Odnotowano istotny statystycznie mniejszy udział procentowy komórek T cytotoksycznych (CD8+TRAIL+) w grupie leczonej metyloprednizolonem $(12 \%) \mathrm{w}$ stosunku do grupy leczonej tylko NLPZ (19,2\%), przedstawiony na rycinie 4 .

\section{Dyskusja}

Analiza płynu stawowego opierała się na badaniu składu krwinek białych, zaangażowanych miejscowo w proces patologiczny w RZS. Istotna część obserwacji dotyczyła limfocytów T, stosunku komórek pomocniczych do cytotoksycznych (indeks CD4/CD8), określenia poziomu aktywacji komórek T oraz odsetka komórek Th i Tc z markerami czynności cytotoksycznej TRAIL i FasL.

Interpretację wyników płynu stawowego w RZS utrudnił brak odpowiedniej próby kontrolnej, co wynikło ze zbyt małej ilości materiału uzyskiwanego podczas artropunkcji osób zdrowych (i jeszcze mniejszej liczby komórek) oraz z oczywistych względów bioetycznych - od osób zdrowych płynu się nie pobiera. W niniejszej pracy, opisującej parametry cytoimmunologiczne chorych leczonych metyloprednizolonem i MTX, grupę kontrolną stanowili więc chorzy $\mathrm{z}$ reguły leczeni tylko preparatami NLPZ. Leczenie zostało podjęte zgodnie $\mathrm{z}$ aktualnie obowiązującymi zaleceniami [12]. Słabą stroną tak pomyślanego badania jest możliwość zaistnienia sytuacji, w której osoby z grupy kontrolnej nie otrzy- 
mały bardziej agresywnego leczenia (GKS ani LMPCh) dlatego, że charakteryzowały się wyjściowo słabszym nasileniem zmian zapalnych. W tym kontekście wyniki pracy należy traktować jako wstępne, a wnioskowanie jest celowo ostrożne i wymaga potwierdzenia w większej liczbie przypadków, zwłaszcza powtarzanych artropunkcji tych samych chorych, co udało się dotąd wykonać jedynie u pojedynczych osób (wyników nie przedstawiano). Podsumowując, porównanie grupy leczonej NLPZ z leczoną metyloprednizolonem i MTX (oraz NLPZ) nie musi jednoznacznie określać faktycznego wpływu danej terapii na parametry cytoimmunologiczne płynu stawowego, na pewno jednak wyniki pracy dają podstawę do przemyśleń i wstępnych wniosków [21].

W wynikach zwraca uwagę duża liczba krwinek białych, w tym granulocytów, limfocytów i makrofagów/monocytów w płynie stawowym. W ocenie zapalnego płynu stawowego szczególna uwaga skupia się na liczebności populacji neutrofilów, które w RZS niszczą tkanki stawowe, produkując w wielkich ilościach wolne rodniki i hydrolazy, w tym proteazy grupy MMP i katepsyny. W RZS wykazano m.in. istotne obniżenie progu aktywacji neutrofilów, wyrażające się między innymi wysoką ekspresją białka receptorowego TREM1 (ang. triggering receptor expressed in myeloid cells 1), co prowadzi pośrednio do nasilonego uwalniania interleukiny-8. Wysoka jest ekspresja ligandu dla aktywatora receptora czynnika transkrypcyjnego $\mathrm{NF} \kappa \mathrm{B}$, czyli głównego czynnika odpowiedzialnego za generację cytokin prozapalnych i propagację zapalenia [22]. Mediatory neutrofilów przyspieszają proliferację błony maziowej i formowanie łuszczki, powodują śmierć chondrocytów i niszczenie stawu. Chemokiny, TNF- $\alpha$, Il-1 $\beta$ oraz IL-6 aktywują inne populacje krwinek białych, w tym limfocyty T. Również temu celowi służy zjawisko netozy (ang. netosis), tj. programowanej genetycznie śmierci z równoczesną prezentacją antygenów limfocytom [23]. Interesującym sposobem oceny toczącego się stanu zapalnego jest określenie stosunku neutrofilów do limfocytów (ang. neutrophil-lymphocyte ratio, NLR) w płynie stawowym. W tym miejscu wypada zaznaczyć, że wg wartości indeksu NLR limfocyty pełnią w tkankach stawu rolę ochronną, neutrofile - szkodliwą [24]. Niestety, w wynikach naszych badań wartość NLR nie zmieniała się istotnie w zależności od leczenia. Warto jednak odnotować, że gdyby liczbę neutrofilów w płynie stawowym przedstawić w wartościach bezwzględnych (vide tabela 2), to są one mniejsze w grupach leczonych MTX i metyloprednizolonem niż w grupie leczonej NLPZ (niestety, różnice w odniesieniu do grupy chorych leczonych NLPZ nie były znamienne, dlatego ich szczegółowo nie prezentowano).

Ważną grupą komórek odczynu swoistego w RZS są limfocyty. Z reguły wykazano dominację komórek $\mathrm{T}$, z różnym, w zależności od przypadku, odsetkiem limfocytów NK i praktycznym brakiem komórek B. Wcześniej wykonanymi odczynami cytoimmunologicznymi udało się wykazać powszechną ekspresję CD45R0 na populacji limfocytów płynu stawowego [nieprezentowane dane własne]. Jest to zgodne z wcześniejszymi badaniami nad populacją komórek 
T w miejscu przewlekłego odczynu zapalnego, która jest zdominowana przez efektorowe komórki T (w RZS zwłaszcza komórki cytotoksyczne T CD8+ oraz pomocnicze CD4+, Th1 i Th17). Być może obecna jest pewna liczba komórek pamięci immunologicznej T $[25,26]$. Komórki NK, chociaż wydają się pełnić drugorzędną rolę, to z pomocą IFN- $\gamma$, TNF- $\alpha$, limfotoksyny- $\beta$ i układu perforyna/ granzymy niszczą tkanki stawowe oraz wpływają na proces osteoklastogenezy poprzez ekspresję RANKL, przyczyniając się do resorpcji kości [21]. Udowodniono również zdolność komórek NK do stymulacji limfocytów T i B [27]. Wg naszej najlepszej wiedzy jesteśmy pierwsi, którzy w świetle wyników pracy sugerują wpływ preparatów GKS na redukcję częstości występowania komórek NK w płynie stawowym. Uważamy to za zjawisko korzystne dla chorego. Limfocyty $\mathrm{T}$ są celem obu analizowanych tu leków - metyloprednizolonu i metotreksatu. W przypadku GKS udokumentowano ich wpływ na liczbę oraz aktywność limfocytów T w RZS. GKS działają na komórki T, hamując ekspresję cytokin prozapalnych, np. IL-2, IL-6 i IFN- $\gamma$, kluczowych w procesie aktywacji limfocytów T. GKS mogą wpływać na syntezę cytokin w momencie transkrypcji, translacji czy potranslacyjnej modyfikacji białek. Ważnym celem molekularnym metyloprednizolonu jest wspomniany czynnik NFkB, a wtórnie - panel prozapalnych cytokin. Już pojedyncza dawka GKS może wywołać limfopenię, i to dla każdej z subpopulacji limfocytów T [28]. GKS zwiększają podatność aktywowanych limfocytów T na proces programowanej śmierci [25]. Gugino i wsp. wykazali wpływ MTX i metylprednizolonu (GKS) na populację limfocytów Th17 oraz komórek Treg krwi obwodowej chorych z RZS. W inkubacji limfocytów z MTX zanotowano spadek odsetka efektorowych limfocytów Th17 chorych z wczesnym RZS, natomiast odsetek komórek Treg podlegał wzrostowi. W zaawansowanej postaci RZS powyższe zmiany były słabiej zaznaczone. Wyniki dla GKS były zbliżone do grupy inkubowanej z MTX [29]. Z kolei Kremer i wsp. ocenili wpływ 36-miesięcznej terapii MTX na stężenia cytokin prozapalnych i odsetki subpopulacji limfocytów T krwi obwodowej chorych z aktywną postacią RZS, wykazując spadek jedynie w przypadku komórek T pamięci o fenotypie CD4+CD29+. Pośrednio przyznano, że wpływ MTX na limfocyty T może zależeć od miejsca ich pobrania [30]. W wynikach naszej pracy skoncentrowano się na fenotypie zewnątrzkomórkowym limfocytów, więc nie podzielono komórek CD4+ na subpopulacje czynnościowe Th1, Th2, Th17 i nTreg. Za to zbadano limfocyty w miejscu ich bezpośredniej czynności efektorowej - w stawie, a nie w krwi obwodowej. Spadek rzeczywistej liczby limfocytów płynu stawowego po podaniu MTX i metyloprednizolonu był prawdopodobnie zamaskowany pozornym wzrostem ich odsetka (równolegle bowiem spadała miejscowo całkowita liczba neutrofilów); niestety, spadek całkowitej liczby limfocytów miał w naszej niezbyt licznej grupie, opracowanej w ramach wstępnych wyników badań, charakter nieznamienny. Jednak wydaje się, że prace innych badaczy koncentrują się - nie do końca zasadnie - na komórkach pomocniczych, podczas gdy w świetle pre- 
zentowanych tu wyników ważniejszym celem obu rozważanych leków są komórki cytotoksyczne CD8+. Wyraziło się to znamiennym statystycznie: a) wzrostem względnym odsetka limfocytów CD4+ w grupie leczonej metyloprednizolonem oraz b) wzrostem indeksu CD4/CD8 w grupie leczonej metotreksatem. Są to oryginalne obserwacje pracy. Uważamy je za korzystne dla chorego.

Uzupełniając dane literaturowe, wypada jeszcze nadmienić, że MTX może działać pośrednio, hamując cytokiny odpowiedzialne za aktywację limfocytów T, w tym komórki cytotoksyczne. Dotyczy to między innymi IL-1 $\beta$, IL-6, IL-8 i IL-17, a więc interleukin kluczowych w patogenezie RZS [30].

Mniej jasne są wyniki (czyli wyraźnie wyższe odsetki) komórek HLA-DR+ wśród limfocytów T płynu stawowego chorych leczonych MTX i metyloprednizolonem, w porównaniu z grupą leczoną NLPZ. Otóż wydaje się, że ekspresja HLA-DR na komórkach T odzwierciedla aktywność procesu chorobowego w RZS i ewentualną skuteczność leczenia [31]. Dane zaczerpnięte z literatury fachowej nie są jednoznaczne [32], wyniki pracy wymagają więc weryfikacji. Na chwilę obecną stawiamy hipotezę, że to właśnie chorzy z aktywnym przebiegiem RZS (i wyjściowo wysokim odsetkiem komórek CD3+HLA-DR+ w płynie stawowym) zostali poddani terapii MTX lub GKS, a wyniki naszych badań odzwierciedlają prawidłowy algorytm działań terapeutycznych; leczenie mogło natomiast nie przełożyć się na spadek (normalizację) ekspresji markera aktywacji limfocytów, tj. HLA-DR. Marker HLA-DR wydaje się w tym ujęciu mieć wyjściowe znaczenie w podejmowaniu decyzji terapeutycznych.

W niniejszym badaniu skupiono się na komórkach o potencjale cytotoksycznym z antygenami TRAIL i FasL, mogącymi indukować apoptozę komórek docelowych, posiadających na powierzchni specyficzne receptory śmierci. Zdolność do indukcji zaprogramowanej śmierci można interpretować dwojako. W przypadku niszczenia komórek struktur stawowych jest to z oczywistych względów proces negatywny. Ale istnieją doniesienia, że komórkami docelowymi limfocytów są aktywowane synowiocyty typu B, budujące łuszczkę stawową $[21,33,34]$. Czynność cytotoksyczna limfocytów mogłaby więc hamować procesu zapalny w RZS. Stąd mógłby właśnie wynikać korzystny prognostycznie efekt niskiej wartości indeksu NLR (vide wyżej). Przy interpretacji wyników należy wziąć pod uwagę trzy okoliczności: 1) Ligandy FasL i TRAIL podlegają ekspresji zarówno na limfocytach cytotoksycznych CD8+, jak i komórkach CD4+; obie populacje na poziomie efektorowym mogą pełnić czynność cytotoksyczną; 2) Limfocyty T TRAIL+ generalnie uczestniczą w zabijaniu innych komórek, podczas gdy limfocyty T FasL + mogą także indukować własną apoptozę - samobójczą lub bratobójczą [25]; 3) w ich powierzchniowej ekspresji (zwłaszcza FasL) uczestniczy aktywacja NFkB, ważny cel molekularny metyloprednizolonu [35].

Podsumowując, wydaje się że profil zmian wywołanych przez GKS (niska ekspresja FasL na limfocytach płynu stawowego oraz słabiej zaznaczone różnice w zakresie ekspresji TRAIL) odpowiada ograniczaniu łuszczki stawo- 
wej przez komórki T, co jest korzystne dla chorego. Mniej jasne wydają się wyniki ekspresji ligandów receptorów śmierci po metotreksacie. Przypuszczalnie poszerzenie prezentowanych tu wyników wstępnych o kolejne przypadki może rzucić więcej światła na to pasjonujące zagadnienie. Należy nadmienić, iż działanie białka TRAIL było dotąd rozważane w przypadku badań dotyczących chorób nowotworowych. Być może warto, w oparciu o przedstawione wyniki, zwrócić uwagę na potencjał tych komórek jako markera aktywności cytotoksycznej płynu stawowego w RZS. Zakładamy, że zebrane informacje ułatwią dobranie odpowiedniego leczenia.

\section{Wnioski}

W zapalnie zmienionym płynie stawowym chorych z RZS terapia metyloprednizolonem lub MTX skutkuje obniżeniem liczby komórek płynu. MTX może sprzyjać eliminacji komórek o fenotypie cytotoksycznym, na co wskazuje znamiennie wyższa wartość indeksu CD4/CD8, w porównaniu z chorymi leczonymi tylko NLPZ. Wysoka ekspresja HLA-DR na limfocytach T płynu stawowego chorych leczonych metyloprednizolonem i MTX może odzwierciedlać wstępną wysoką aktywność procesu zapalnego, a nie wpływ zastosowanego leczenia. Metyloprednizolon z reguły obniża ekspresję TRAIL i FasL na limfocytach, szczególnie zaznaczony był spadek wartości odsetka limfocytów CD8+TRAIL+. Można to zinterpretować jako obniżenie potencjału cytotoksycznego krwinek płynu stawowego. Badanie cytoimmunologiczne płynu stawowego może mieć znaczenie w ocenie skuteczności leczenia RZS lub może stanowić pomocniczą informację o konieczności włączenia odpowiedniego leczenia.

\section{Bibliografia}

1. Okada $\mathrm{Y}, \mathrm{Wu} \mathrm{D}$, Trynka $\mathrm{G}$ et al. Genetics of rheumatoid arthritis contributes to biology and drug discovery. Nature. 2014; 506: 376-381.

2. Aletaha D, Neogi T, Silman AJ et al. 2010 Rheumatoid arthritis classi cation criteria: an American College of Rheumatology/European League Against Rheumatism collaborative initiative. Arthritis Rheum. 2010; 62: 2569-2581.

3. Scott DL, Wolfe F, Huizinga TW. Rheumatoid arthritis. Lancet. 2010; 376: 10941108.

4. Bellucci E, Terenzi R, La Paglia GMC et al. One year in review 2016: pathogenesis of rheumatoid arthritis. Clinical and Experimental Rheumatology. 2016; 34 : 793-801.

5. Van Venrooij WJ, Van Beers JJ, Pruijn GJ. Anti-CCP Antibody, a Marker for the Early Detection of Rheumatoid Arthritis. Ann NY Acad Sci. 2008; 1143: 268-285.

6. Steiner G, Smolen J, Autoantibodies in rheumatoid arthritis and their clinical significance. Arthritis Researches. 2002; 4: 1-5. 
7. Darrah E, Andrade F. Rheumatoid arthritis and citrullination. Current Opinion in Rheumatology. 2018, 30: 72-78.

8. Doorenspleet ME, Klarenbeck PL, de Hair MJ et al. Rheumatoid 47. arthritis synovial tissue harbours dominant B-cell and plasma-cell clones associated with autoreactivity. Ann Rheum Dis. 2014; 73: 756-762.

9. Filipowicz-Sosnowska A, Stanisławska-Biernat E, Zubrzycka-Sienkiewicz A. Reumatoidalne zapalenie stawów. Reumatologia. 2004; 42 (1): 1-16.

10. Katchamart W, Trudeau J, Phumethum V, Bombardier C. Methotrexate monotherapy versus methotrexate combination therapy with non-biologic disease modifying anti-rheumatic drugs for rheumatoid arthritis. Cochrane Database Syst Rev. 2010; 14 (4): 495-502.

11. Tłustochowicz W, Brzosko M, Filipowicz-Sosnowska A et al. Stanowisko Zespołu Ekspertów Konsultanta Krajowego ds. Reumatologii w sprawie diagnostyki $i$ terapii reumatoidalnego zapalenia stawów. Reumatologia. 2008; 46: 111-114.

12. Smolen J.S., Landewé R, Bijlsma J et al. EULAR recommendations for the management of rheumatoid arthritis with synthetic and biological disease-modifying antirheumatic drugs: 2016 update. Annals of the Rheumatic Diseases. 2017; 76: 960-977.

13. Zimmermann-Górska I. Zastosowanie leków biologicznych $w$ chorobach reumatycznych. Przew Lek. 2007; 3: 40-47.

14. Zimmermann-Górska I. Postępy $w$ diagnostyce $i$ terapii $w$ reumatologii. Przew Lek. 2008; 1: 124-128.

15. Scott DL, Wolfe F, Huizinga TW. Rheumatoid arthritis. Lancet. 2010; 376 (9746): 1094-108.

16. Liu H, Pope MR. The role of apoptosis in rheumatoid arthritis. Current Opinion in Pharmacology. 2003; 3: 317-322.

17. Darrieutort-Laffite C, Boutet MA, Chatelais $\mathrm{M}$ et al. IL-1 $\beta$ and TNF $\alpha$ promote monocyte viability through the induction of GM-CSF expression by rheumatoid arthritis synovial fibroblasts. Mediators of Inflammation, 2014; 1-10.

18. Zimmermann-Górska I, Białkowka-Puszczewicz G, Puszczewicz M. Atlas ptynu stawowego. Wyd. Lekarskie PZWL, 1995.

19. Balicka-Ślusarczyk B, Dyczek A, Marszałek A et al. Wybrane cytokiny i ich receptory w dolnych drogach oddechowych palaczy papierosów. Czy dym tytoniowy wplywa na stan polaryzacji immunologicznej Th1/Th2 w śródmiąższowych chorobach płuc?. Przegl. Lek. 2011; 68 (10): 684-688.

20. Kopiński P, Szczeklik J, Lackowska B et al. Flow cytometric characteristics of alveolar lymphocytes obtained by bronchoalveolar lavage (BAL) in the control group - proposal of normal value range of AL subsets in non-smokers. Central Eur J Immunol. 2004; 29: 63-72.

21. Guo X, Wang Y, Xu D et al. Rheumatoid arthritis: pathological mechanisms and modern pharmacologic therapies. Review article. Bone Research. 2018; 6: 15.

22. Poubelle PE, Chakravarti A, Fernandes MJ et al. Differential expression of RANK, $R A N K-L$, and osteoprotegerin by synovial fluid neutrophils from patients with rheumatoid arthritis and by healthy human blood neutrophils. Arthritis Res Ther. 2007; 9 (2): R25. 
23. Cecchi I, Arias de la Rosa I, Menegattia E et al. Neutrophils: Novel key players in Rheumatoid Arthritis. Current and future therapeutic targets. Autoimmun Rev. 2018, Sep 11. pii: S1568-9972(18)30216-7.

24. Abd-Elazeem MI, Mohamed RA. Neutrophil-lymphocyte and platelet-lymphocyte ratios in rheumatoid arthritis patients: Relation to disease activity. The Egyptian Rheumatologist. 201710.1038/s41413-018-0016-9.

25. Kopiński P. Badania nad apoptoza limfocytów pęcherzykowych $w$ wybranych śródmiąższowych chorobach płuc [rozprawa habilitacyjna]. Bydgoszcz 2012.

26. Mellado M, Martínez-Muñoz L, Cascio G et al. T Cell Migration in Rheumatoid Arthritis. Front Immunol. 2015; 6: 384.

27. Ahern DJ., Brennan FM. The role of Natural Killer cells in the pathogenesis of rheumatoid arthritis: Major contributors or essential homeostatic modulators?. Immunology Letters. 2011; 136: 115-112.

28. Townsend HB, Saag KG. Glucocorticoid use in rheumatoid arthritis: Benefits, mechanisms, and risks. Clinical and Experimental Rheumatology. 2004; 22 (35): 77-82.

29. Guggino G, Giardina A, Ferrante A et al. The in vitro addition of methotrexate and/ or methylprednisolone determines peripheral reduction in Th17 and expansion of conventional Treg and of IL-10 producing Th17 lymphocytes in patients with early rheumatoid arthritis. Rheumatology International. 2015; 35 (1): 171-175.

30. Kremer JM, Lawrence DA, Hamilton R et al. Long-term study of the impact of methotrexate on serum cytokines and lymphocyte subsets in patients with active rheumatoid arthritis: correlation with pharmacokinetic measures. RMD Open. 2016; 2:e00287.

31. Libura M. Wptyw podanego dostawowo autologicznego osocza bogatoptytkowego (platelet-rich plasma, PRP) na miejscowy obraz cytoimmunologiczny $w$ reumatoidalnym zapaleniu stawów. Ocena hamowania potencjału cytotoksycznego limfocytów płynu stawowego [rozprawa doktorska]. Bydgoszcz 2018 (w przygotowaniu).

32. Dulic S, Vásárhelyi Z, Sava F et al. T-Cell Subsets in Rheumatoid Arthritis Patients on Long-Term Anti-TNF or IL-6 Receptor Blocker Therapy. Mediators of Inflammation. 2017; 2017:6894374.

33. Malemud CJ. Matrix Metalloproteinases and Synovial Joint Pathology. Prog Mol Biol Transl Sci. 2017; 148: 305-325.

34. Bartok B, Firestein GS. Fibroblast-like synoviocytes: key effector cells in rheumatoid arthritis. Immunological Reviews. 2010; 233 (1): 233-255.

35. Allen LV Jr, Yanchick VA, Maness DD. Dissolution rates of corticosteroids utilizing sugar glass dispersions. J Pharm Sci. 1977; 66 (4): 494-497. 


\title{
Cytoimmune image of synovial fluid in rheumatoid arthritis. Evaluation of the impact of selected treatment methods
}

\begin{abstract}
Introduction: Synovial fluid aspiration of patients with rheumatoid arthritis (RA) provides important information on the activity of the local inflammation. Synovial T lymphocytes, including cells positive with ligands of death receptors, i.e. Fas ligand (FasL) and TRAIL (TNF-related apoptosis-inducing ligand), both of which play an important role in RA pathogenesis. The first-line treatment of RA is methotrexate (MTX), but glucocorticoids (as prednisone) and non-steroid anti-inflammatory drugs (NSAIDs) are also used. The impact of treatment on the immune profile of synovial fluid in RA has not yet been cleared.

Objective: Characteristics of the influence of prednisone and MTX treatment on the cytoimmunological pattern of synovial fluid in RA patients.

Material and methods: Synovial fluid was harvested from RA patients treated with prednisone $(\mathrm{n}=11)$ and MTX $(\mathrm{n}=6)$. The control group consisted of patients receiving NSAIDs only $(\mathrm{n}=19)$.

The total cell number (TCN), the percentage of leukocyte populations and the phenotype of lymphocytes, including FasL and TRAIL expression on Th and Tc cells, was analyzed. Results: In the prednisone and MTX-treated groups, a decline in TCN was found. The increased value of the CD4/CD8 index in the MTX group was statistically significant, as compared to the NSAIDs-treated group (median: 1.2 vs $0.7, \mathrm{p}<0.05$ ). In prednisone-treated patients, a statistically significant decrease in the percentage of lymphocytes T FasL+ and TRAIL+ was observed (i.e. median of CD8+TRAIL+ cells was $12.0 \%$ vs $19.2 \%$ in the NSAIDs-treated group, $\mathrm{p}<0.05$, U-Mann-Whitney test).

Conclusions: In the synovial fluid of patients treated with prednisone, there was a decrease in the lymphocyte cytotoxicity markers compared to the group treated only with NSAIDs. Parallel changes in the MTX group were non-significant. MTX seems to increase the value of the CD4/CD8 index, which can be interpreted as a result of CD8+ cytotoxic cell elimination. Cytological and immunological analysis of synovial fluid may be useful to assess the efficacy of local treatment.
\end{abstract}

Key words: rheumatoid arthritis, synovial fluid, methotrexate, prednisone 